\title{
Diseminasi Teknologi Mesin Genset Tenaga Surya Bagi Masyarakat Terdampak Bencana Gunung Merapi Desa Wukirsari Kecamatan Cangkringan Kabupaten Sleman
}

\author{
Achmad Buchori ${ }^{1}$, Suwarno Widodo ${ }^{1}$, Sigit Ristanto ${ }^{1}$, Listya Endang Artiani ${ }^{2}$ \\ ${ }^{1}$ Universitas PGRI Semarang, ${ }^{2}$ Universitas Islam Indonesia \\ buccherypgri@gmail.com
}

Submitted: 8 December 2018. Revised: 23 June 2019. Accepted: 27 July 2019

\section{Key word:}

Dissemination; product innovation; solar power generator engine

\section{Kata Kunci}

Diseminasi; Inovasi produk; Mesin genset tenaga surya

\section{Abstract}

The problem experienced by Wukirsari Village as one of the areas affected by the Mount Merapi disaster is the frequent occurrence of PLN power outages. To overcome this problem, the dissemination of technology products to the community aims to improve the ability of Wukirsari villagers to make natural electricity based on solar power and use solar power generator technology and be able to increase the value of sales and marketing. Outputs generated from this activity include the development of a number of group members, training in the use and maintenance of solar generator sets, training in the manufacture of solar engine generator sets, good financial management training and product sales and marketing training. This activity has resulted in: (1) solar generator products that have been carefully prepared with good results by the UPGRIS team, (2) villagers of Wukirsari are able to treat and use properly and correctly, (3) symbolic delivery to 3 residents solar power generator with capacity, 900 Watt, 1200 Watt and 1500 Watt.

\section{Abstrak}

Permasalahan yang dialami oleh Desa Wukirsari sebagai salah satu wilayah yang terdampak bencana gunung merapi adalah sering terjadinya pemadaman listrik PLN. Untuk mengatasi masalah tersebut kegiatan diseminasi produk teknologi ke masyarakat ini bertujuan untuk meningkatkan kemampuan warga desa Wukirsari dalam membuat tenaga listrik alami berbasis tenaga surya dan menggunakan teknologi genset tenaga surya serta mampu melakukan peningkatan nilai penjualan dan pemasarannya. Luaran yang dihasilkan dari kegiatan ini antara lain pengembangan jumlah anggota kelompok, pelatihan penggunaan dan perawatan mesin genset tenaga surya, pelatihan pembuatan produk mesin mesin genset tenaga surya, pelatihan manajemen finansial yang baik serta pelatihan penjualan dan pemasaran produk. Kegiatan ini telah menghasilkan: (1) produk genset tenaga surya yang telah dibuat secara seksama dengan hasil yang baik oleh tim UPGRIS, (2) warga desa Wukirsari mampu merawat dan memakai secara baik dan benar, (3) penyerahan simbolis ke warga sebanyak 3 alat mesin genset tenaga surya dengan kapasitas, 900 Watt, 1200 Watt dan 1500 Watt. 


\section{PENDAHULUAN}

Secara administratif Desa Wukirsari merupakan bagian dari wilayah Kecamatan Cangkringan Kabupaten Sleman Provinsi Daerah Istimewa Yogyakarta. Desa Wukirsari mempunyai orbitasi berupa jarak dari pusat pemerintahan kecamatan $2 \mathrm{~km}$, sedangkan dari ibukota kabupaten 17 km dan dari ibukota propinsi $22 \mathrm{~km}$. Batasbatas wilayah Desa Wukirsari adalah sebagai berikut: Sebelah Utara Desa Hargobinganun, Kecamatan Pakem, Sebelah Timur Desa Glagaharjo, Kecamatan Cangkringan, Sebelah Selatan Desa Umbul martani, Desa Widodomartani Kecamatan Ngemplak, Sebelah Barat Desa Umbulharjo, Desa Pakembinangun Kecamatan Pakem.

Lahan di daerah Desa Wukirsari sebagian besar dimanfaatkan untuk sektor pertanian, yaitu berupa sawah, ladang dan perkebunan. Dengan demikian Desa Wukirsari mempunyai potensi di sektor pertanian yang cukup besar karena lebih dari setengah luas atau $65,51 \%$ luas wilayah desa tersebut digunakan untuk sektor pertanian.

Berdasarkan evaluasi pelaksanaan rehabilitasi dan rekonstruksi pasca bencana erupsi gunung Merapi diperoleh bahwa di Kecamatan Cangkringan setidaknya terdapat 3 (tiga) jembatan yang masih perlu diperbaiki. Selain itu, fasilitas air bersih masih dibutuhkan di beberapa Hunian tetap (Pujianto, Astuti, \& Martyana, 2017).

Tidak stabilnya ketersediaan Pasokan listrik PLN yang mengakibatkan sering terjadi pemadaman listrik. Pemadaman listrik yang sering terjadi berimbas juga terhadap pasokan air bersih juga pasokan air untuk pertanian. Selain itu, karena listrik merupakan sumber utama dalam membantu perekonomian warga desa Wukirsari.

Beberapa alternatif permasalahan energi listrik adalah penggunaan energi alam sebagai pembangkit listrik. Penggunaan bahan baku energi terbarukan seperti sinar matahari atau tenaga surya untuk pembangkit listrik ataupun genset belum banyak dilakukan. Sementara potensi energy terbarukan tersebut di Indonesia cukup besar, terutama untuk daerah-daerah pantai dan pegunungan (Nugroho, 2013).

Beberapa penelitian menunjukkan bahwa pemanfaatan tenaga surya untuk daya genset atau pembangkit listrik sudah semakin banyak. Hal ini disebabkan oleh ketersediaan produk baterai untuk menyimpan energi surya sudah sangat banyak di Indonesia (Kumara, 2010).

Kondisi dan potensi Desa Wukirsari dan kemudahan alat untuk membuat 
pembangkit listrik ataupun genset tenaga surya menjadikan tim pengabdi memilih desa tersebut sebagai mitra diseminasi mesin genset yang dibuat oleh Universitas PGRI Semarang dengan harapan warga desa Wukirsari mampu membuatnya secara mandiri.

Diseminasi yang dilakukan dalam pengabdian ini melibatkan masyarakat secara aktif. Pelibatan masyarakat ini bertujuan agar pemberdayaan masyarakat dalam penggunaan mesin genset tenaga surya dapat dilakukan secara mandiri dan dapat memasarkan genset. Model pemberdayaan ini sejalan dengan upaya pengurangan risiko bencana hidrometeorologi melalui pemetaan partisipatif tata ruang desa Tasikmadu dengan Sistem Informasi Geografis (SIG dan Sistem informasi Desa (SID) sebagai media penyadaran masyarakat. Partisipasi aktif dari masyarakat sangat menentukan hasil pemberdayaan masyarakat (Sari, 2017).

Pemberdayaan masyarakat yang dilakukan dengan partisipasi aktif masyarakat juga dilakukan di Desa Karangsong dalam pengembangan polikultur bandeng dan udang (Darmansah, Nugroho, \& Supriyono, 2017). Kegiatan pelatihan tentang bio security yang melibatkan masyarakat juga merupakan solusi yang tepat bagi para petani tambak di Desa Wonoagung Kecamatan Karangtengah Kabupaten Demak dalam memaksimalkan potensi lahan tambaknya bagi budidaya ikan Bandeng (Dzakiy, Buchori, Nurdyansyah, Istiyaningsih, \& Nindita, 2017).

Pemberdayaan masyarakat yang juga menggunakan metode community participative juga dilakukan di Desa Bendosari yang melibatkan remaja sebagai pemandu wisata (Egar, Fahmi, Yulianti, \& Musarokah, 2017)

\section{METODE}

Pengabdian ini dilaksanakan dengan memilih mitra dari Desa Wukirsar. Pilihan tersebut adalah Kelompok "Dukuh Gungan dan Dukuh Srodokan”. Kelompok ini beranggotakan 20 orang yang mayoritas adalah bapak-bapak dan remaja yang tidak bekerja. Pemilihan kelompok dukuh ini didasarkan pada lokasi dan potensi masyarakat yang akan diberdayakan untuk menerima diseminasi teknis dan dilatih untuk dapat membuat genset secara mandiri.

Metode dan Tahapan dalam Penerapan Teknologi Kepada Masyarakat ditunjukkan terdiri dari:

1. Identifikasi kebutuhan masyarakat: identifikasi kebutuhan masyarakat 


\begin{abstract}
dilakukan dengan wawancara dan observasi langsung untuk melihat berapa banyak daya yang dibutuhkan kelompok dalam kebutuhan listrik sehari-hari. Selain itu juga dihitung kapasitas rata-rata sinar matahari yang ada di Desa Wukirsari.
\end{abstract}

2. Perancangan mesin genset: dilakukan dengan mempertimbangkan unsur fungsi, kemudahan pengoprasionalan, estetika, dan kemudahan mencari bahan untuk duplikasi.

3. Pembuatan mesih genset dilakukan dengan metode partisipasi bersama antara tim pengabdi dengan mitra,
4. Uji operasi,

5. Pendampingan operasional,

6. Diseminasi teknologi kepada masyarakat yang lebih luas melalui sosialisasi alat, pelatihan penggunaan alat, pelatihan pembuatan alat, pelatihan manajemen finansial, pelatihan pemasaran.

Diseminasi teknologi dan pendampingan operasional menjadi fokus dalam pengabdian ini. Secara ringkas metode disajikan pada Tabel 1 .

Tabel 1. Metode dan Tahapan

\begin{tabular}{lll}
\hline No & \multicolumn{1}{c}{ Kegiatan } & \multicolumn{1}{c}{ Metode } \\
\hline 1 & Identifikasi Kebutuhan Masyarakat & Wawancara dan Observasi \\
& & Langsung \\
2 & Perancangan & Diskusi \\
3 & Pembuatan & Sosialisasi, praktek dan diskusi \\
4 & Uji Operasi & Pengamatan \\
5 & Pendampingan Operasional & Diskusi, praktek dan tanya jawab \\
6 & Diseminasi teknologi tersebut kepada & Sosialisasi, pelatihan, \\
& masyarakat/mitra & pendampingan \\
\hline
\end{tabular}

HASIL

$$
\text { Informasi yang didapatkan }
$$

mengenai kebutuhan warga desa Wukirsari melalui sosialisasi analisis kebutuhan warga pasca erupsi gunung merapi adalah data bahwa $80 \%$ masyarakat membutuhkan genset tenaga surya dalam menerangi desa. Selama ini warga kesulitan penerangan ketika evakuasi saat terjadi erupsi gunung merapi.

Kegiatan yang telah dilakukan
dalam program Diseminasi Teknologi
Mesin Genset Tenaga Surya bagi
Masyarakat Terdampak Bencana Gunung
Merapi Desa Wukirsari Kecamatan


Cangkringan Kabupaten Sleman adalah sebagai berikut:

1) Sosialisasi program kegiatan Diseminasi Genset Tenaga Surya dilakukan kepada 20 warga yang terdiri dari laki-laki dewasa dan remaja yang memiliki potensi sebagai penggerak pembuatan;

2) Pelatihan penggunaan dan perawatan mesin genset tenaga surya. Pelatihan menggunakan genset tenaga surya yang telah dibuat oleh tim pengabdi bersama dengan UPGRIS dan mitra yaitu CV Omset Pintar;

3) Pelatihan pembuatan mesin genset tenaga surya untuk dapat digunakan dalam kehidupan sehari-hari.

4) Pelatihan manajemen finansial produksi genset tenaga surya,

5) Pelatihan penjualan melalui pemasaran online dan offline melalui blog dan media sosial lain.

\section{PEMBAHASAN}

Kegiatan Diseminasi ini dilaksanakan dalam waktu 8 (delapan) bulan dimulai sejak proposal ini disetujui sampai bulan September 2018. Kegiatan yang berlangsung sebagai berikut:

1) Sosialisasi program kegiatan

Sosialisasi dilaksanakan kepada dua kelompok yaitu Dukuh Gungan dan Dukuh Srodokan yang berjumlah 20 orang. Kelompok ini berkomitmen untuk menjadi agen penerus teknologi dari tim pengabdi;

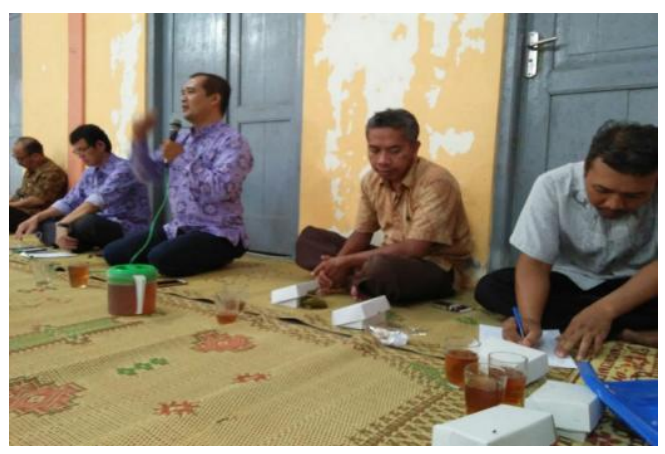

Gambar 1. Sosialisasi program

2) Pelatihan penggunaan dan perawatan mesin genset tenaga surya. Kegiatan ini dipraktikkan oleh tim pengabdi menggunakan genset yang sudah ada dan di hadapan kelompok mitra. Kegiatan ini juga menggunakan metode diskusi dan tanya jawab untuk memperdalam pemahaman peserta. Pelatihan ini juga memberikan pemahaman bahwa Sinar matahari yang masuk ke solar cell dilanjutkan charge controller untuk diubah bentuk arusnya, kemudian disimpan di baterai menjadi arus DC. Melalui inverter diubah lagi menjadi arus $\mathrm{AC}$ sehingga siap digunakan oleh masyarakat desa Wukirsari. 


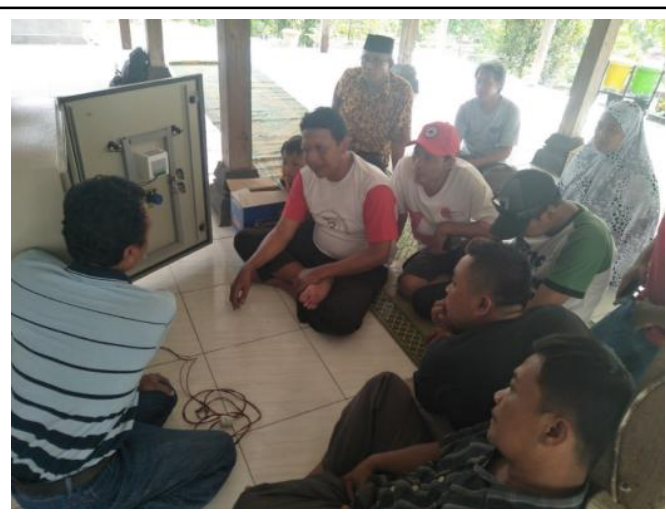

Gambar 2. Pelatihan pengoperasian dan perawatan genset

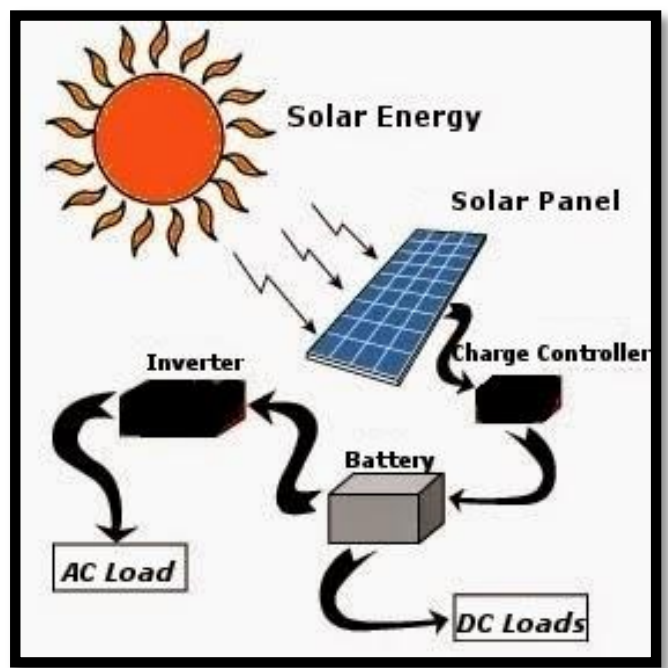

Gambar 3. Cara pemasangan genset

3) Pelatihan pembuatan mesin genset tenaga surya kepada kelompok mitra. Metode yang digunakan adalah mempraktikkan dan langsung ditirukan oleh peserta dalam merakit komponen dan kompartemen yang digunakan dalam membuat genset.

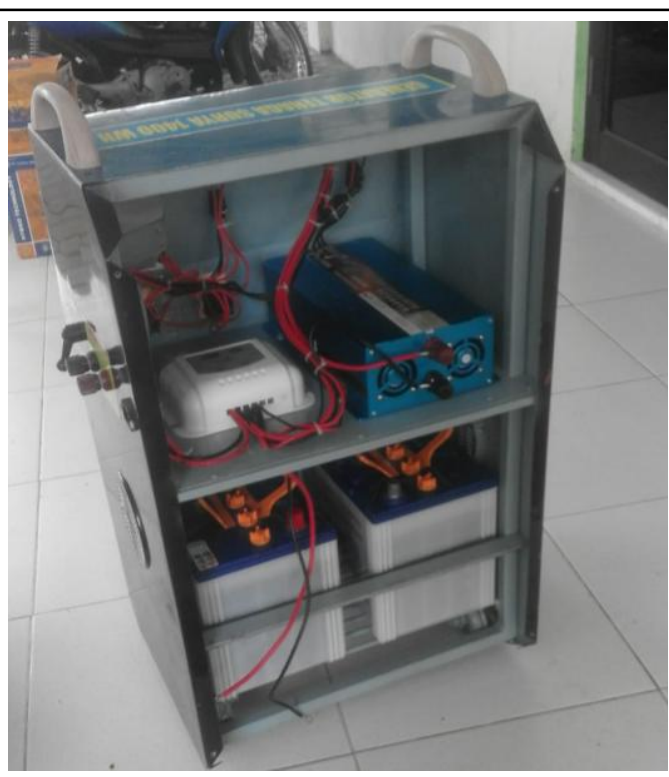

Gambar 4. Mesin Genset yang sudah dirakit

Setelah rangkaian selesai dibuat, kemudian dipasang bersama dengan warga.

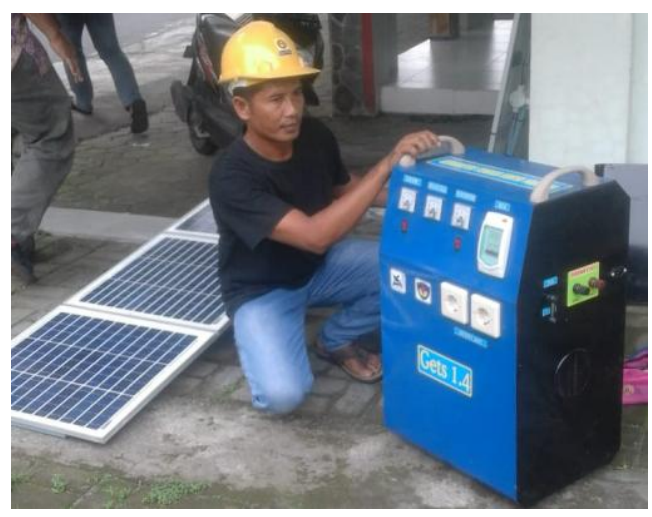

Gambar 5. Produk genset tenaga surya 


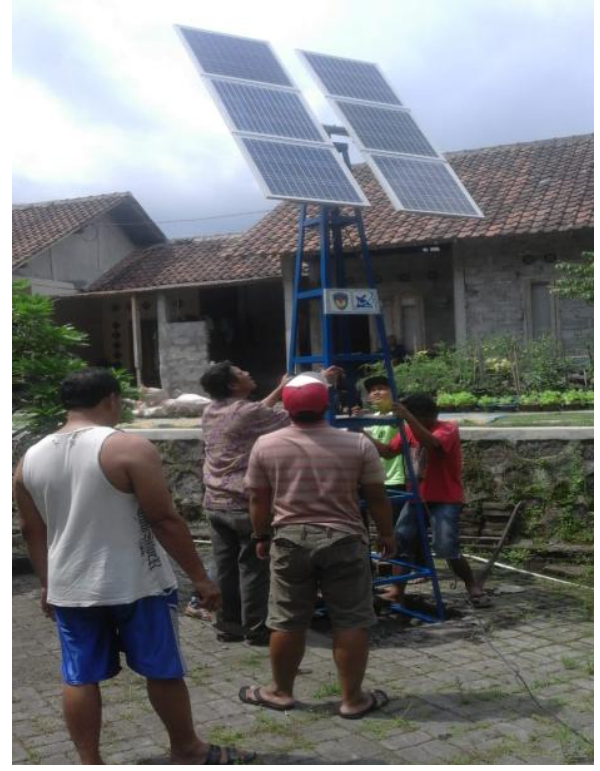

Gambar 6. Pemasangan genset oleh warga

4) Pelatihan manajemen financial. Tahapan ini dilaksanakan dengan membuat kalkulasi sederhana kebutuhan yang dibutuhkan untuk membuat dan memasarkan genset sehingga dapat terjual dan mendatangkan benefit bagi kelompok mitra.

5) Pelatihan penjualan melalui pemasaran online dan offlin dilakukan dengan cara melatih warga membuat web pemasaran via blog, twitter, facebook dan lain-lain sehingga masyarakat desa Wukirsari tertarik untuk memasarkan produk yang dihasilkan secara online. . Pelatihan penjualan dilakukan dengan pendekatan manajemen Usaha dan keuangan UMKM (Bismala, 2017)

Program desiminisasi ini telah menghasilkan tiga genset tenaga surya dengan kapasitas masing-masing 900 Watt, 1200 Watt, dan 1500 Watt. Ketiga alat tersebut dipasang di wilayah Desa Wukirsari di pedukuhan yang berbeda. Tiap alat dikelola oleh kelompok masyarakat yang telah diberi pelatihan sebelumnya.

\section{SIMPULAN DAN SARAN}

Simpulan kegiatan yang telah dilakukan dalam program Diseminasi Teknologi Mesin Genset Tenaga Surya Bagi Masyarakat Terdampak Bencana Gunung Merapi Desa Wukirsari Kecamatan Cangkringan Kabupaten Sleman adalah sebagai berikut:

a) Masyarakat desa Wukirsari sangat antusias dalam pelatihan cara penggunaan genset tenaga surya sehingga meningkatkan kenyamanan warga

b) Tingkat antusiame selama mengikuti kegiatan diseminasi

c) Akan dilakukan monitoring dan evaluasi pelatihan marketing penjualan genset tenaga surya pada bulan oktober 2018.

Secara umum produk genset tenaga surya sangat diminati warga desa Wukirsari karena mampu menjadi solusi atas terjadinya mati lampu akibat erupsi gunung merapi sebagai alternatif listrik PLN tidak hidup, adapun saran yang perlu 
diperbaiki adalah:

a) Peserta pelatihan perlu ditambah lagi, sehingga tidak hanya 20 warga perwakilan RT dan RW saja

b) Pelatihan perakitan produk genset tenaga surya perlu dilakukan secara berulang, sehingga warga lebih mudah menggunakannya

c) Perlu diajak karang taruna sebagai wakil generasi muda dalam membangun desa Wukirsari.

\section{UCAPAN TERIMA KASIH}

Ucapan terima kasih kami tujukan pada Kementerian Ristekdikti yang telah memfasilitasi terselenggaranya Diseminasi Teknologi Mesin Genset Tenaga Surya Bagi Masyarakat Terdampak Bencana Gunung Merapi Desa Wukirsari Kecamatan Cangkringan Kabupaten Sleman. Kepada Dusun di lingkup Desa Wukirsari, juga Kepala Desa Wukirsari yang atas sambutan dan dukungan selama kegiatan dilaksanakan.

\section{DAFTAR PUSTAKA}

Abi, I. K. (2018). Strategi Badan Usaha

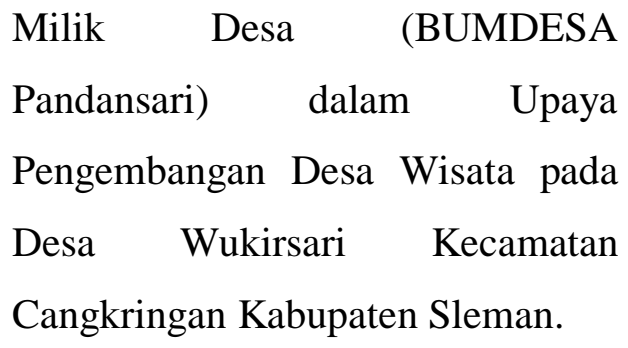

Bismala, L. (2017). Model Manajemen Usaha Mikro Kecil dan Menengah (UMKM) untuk Meningkatkan Efektivitas Usaha Kecil Menengah. Jurnal Entrepreneur dan Entrepreneurship, 5(1), 19-26.

Darmansah, A., Nugroho, T., \& Supriyono, E. (2017). Pemberdayaan masyarakat melalui pengembangan polikultur bandeng dan udang di Desa Karangsong, Indramayu, Jawa Barat. Agrokreatif Jurnal Ilmiah Pengabdian kepada Masyarakat, 2(2), 92-99.

Dzakiy, M. A., Buchori, A., Nurdyansyah, F., Istiyaningsih, R., \& Nindita, V. (2017). Pembuatan Desain Kolam Ikan Bandeng Berbasis Konsep Biosecurity Bagi Masyarakat Petani Tambak di Pesisir Kabupaten Demak. Journal of Dedicators Community, 1(2), 103-113.

Egar, N., Fahmi, D. A., Yulianti, F., \& Musarokah, S. (2017). Pemberdayaan Remaja Desa Wisata Bendosari Kecamatan Plantungan Kabupaten Kendal Melalui Pelatihan Kepemanduwisataan. Journal of Dedicators Community, 1(2), 150-157.

Kumara, N. (2010). Pembangkit listrik tenaga surya skala rumah tangga urban dan ketersediaannya di 
Indonesia. Majalah Ilmiah Teknologi Elektro.

Ningtyas, L. H. (2017). Evaluasi Implementasi Pembinaan Akhlak Anak di Panti Asuhan Al-Hikmah Desa Plupuj, Cangkringan, Sleman. Nugroho, W. T. (2013). Pengembangan Produk Genset Energi Surya dan Angin Terpadu Berbasis Quality Function Deployment. Jurnal Ilmiah Inovasi, 13(1). https://doi.org/10.25047/jii.v13i1.6 1

Pujianto, A., Astuti, P., \& Martyana, D. C. (2017). Evaluasi Pelaksanaan Rehabilitasi dan Rekonstruksi Pasca Bencana Erupsi Merapi Tahun 2010. UMY.

Sari, D. E. (2017). Pendampingan Masyarakat Desa Tasikmadu dalam Upaya Pengurangan Risiko Bencana Hidrometeorologi Melalui Pemetaan Partisipatif Tata Ruang Desa dengan SIG (Sistem Informasi Geografis) dan SID (Sistem Informasi Desa) Sebagai Media Penyadaran Masyarakat $(\mathrm{PhD}$ Thesis). UIN Sunan Ampel Surabaya. 